Ian Smith

Pākehā Settlements in a Māori World:

New Zealand Archaeology 1769-1860

Wellington: Bridget Williams Books, 2019, 328 pp

\title{
Setting the Scenes of Early Pākehā
}

\section{PETER HOWLAND}

Pākehā Settlements in a Mãori World, by Ian Smith, honorary associate professor of archaeology at the University of Otago and recently retired after four decades of research and teaching, is an excellent introduction to the subtleties, complexities, and general historical trajectories of early colonial Pākehā settlement in Aotearoa from 1769-1860. This is a period when Pākehā settlements of whatever hue were dominated by in-situ Māori economic, social, and political modalities. This includes the early advent of offshore-anchored exploratory ships and temporary seal-hunting camps on to more permanent settlements (including the unplanned, fleeting, and/or enforced by traumatic, even comical, circumstances, but also intentional and fledging missionary, early trading, New Zealand Company, and provincial government settlements). Smith argues that during this time, the agency of the indigenous peoples of Aotearoa was in the ascendancy, and Māori often chose on what terms they engaged with Pākehā settler culture, and what aspects they engaged with, adopted, adapted, and/or rejected. Or, as Smith states, this was the period before the five-fold increase in Pākehā population from the 1860s onwards, before the correlated decline of Māori populations due to disease and deprivation, before 
their initial enclaving within rural areas, and before the 'onset of a more brutal phase of colonisation by military force and confiscation of Māori land and resources [that] changed the balance of power'. ${ }^{1}$

Written for a lay, literate audience (think the staunch defenders of Concert FM or eager secondary-school and undergraduate students), and clearly by an academic of long-standing practice who is deeply embedded within their discipline, highly skilled, and vastly knowledgeable, Pākehā Settlements in a Mãori World deftly outlines the enablements and limitations of 'historical archaeology', which is essentially a methodological amalgam of material archaeology and documentary history, of which Smith is one of the founders and key proponents. Among the limitations of this methodology are just what specific components of material culture are preserved. Somewhat ironically-especially given the research method in its totality-soft tissue materials like paper, and also textiles, rarely survive for long periods of time in middens. What is, and what is not, archaeologically exhumed is another important consideration, with many potentially illuminating archaeological sites currently lying under existing buildings and tar-sealed roadways, while other more accessible sites remain unexcavated due to a lack of research funds and/or institutional support. On the historical front, the primary limitation concerns what documents were first written and archived. Essentially, the illiterate and harried poor rarely leave documentary traces, so historical documents tend to reflect the interests and narratives of the powerful and aspirational. Although such an evidential skew is countered by the material-culture fact that very few residences of wealthy settlers from the period of 1840 to 1860 have been excavated as there were significantly fewer compared to the residences of the poor. What's more, they were built of superior materials that have lasted (albeit often in modified, origin-eclipsing and period-conflating states) so that such buildings are still often in active use and inhabited by the currently well-endowed, who are typically disinclined to allow archaeological digs under their 'Master-chef' kitchens.

1 Ian Smith, Pākehā Settlements in a Māori World: New Zealand Archaeology 1769-1860 (Wellington: BWB, 2019), 276. 
Nevertheless, whenever either or both material culture and documentary records are accessible, a rich and often nuanced history of Pākehā settlement may be constructed. In this, Smith identifies five key phases of Pākehā settlement from 1769 to 1860. First, the 'Explorer' phase (1769 to 1791), when few or any overnight camps were established. Of this phase, four anchors lost during a violent storm on 28 December 1769 from the St Jean Baptiste, captained by French explorer Jean-François-Marie de Surville, currently constitute the entire material archaeological record. Second, the 'Sojourning Settler' phase (1792 to 1814), which was based on the resource extraction of seals, whales, and timber and from which limited archaeological evidence of temporary residences built from both local and non-local materials, and even caves, exists. Third, the 'Permanent Resident' phase (1814 to 1828), which commenced when Samuel Marsden established a mission station at Hohi in the Bay of Islands and from which more significant archaeological evidence remains, including household ceramics, musket balls, nails, beads, housing foundations, dwellings, textiles, and so on. Fourth, the 'Dispersal and Diversification' phase (1829 to 1839) when Pākehā, previously restricted to the far-north and far-south of Aotearoa, began to spread elsewhere, with 22 new mission stations established south of the Bay of Islands in the 1820s, for example. A short-lived surge in demand for flax (1828 to 1832) and whales (1829 to 1839) prompted numerous other settlements, including the first Pākehā township, which was initially built within the Ngāti Manu village on Kororāreka beach in the 1820 s and which then expanded in the early 1830 s with the building of 11 wooden houses and a diverse range of commercial enterprises.

The fifth and final phase of Pākehā settlement documented by Smith is the 'Colonial Settlement and Governance' phase (1840 to 1860). Although this phase significantly witnessed the signing of the Treaty of Waitangi, as Smith importantly notes, by this point, many Māori already considered themselves to be in formal relationship with the British Crown as indicated by their repeated pleas to Crown representatives in New South Wales to actively intervene and curb Pākehā mis-dealings and to relieve them of the burden of ruling over increasingly larger Pākehā communities and policing 
the Māori-Pākehā interface. Moreover, many believed they had already initiated a formal relationship with the Crown through generating and committing to He Wakaputanga o te Rangatiratanga o $\mathrm{Nu}$ Tireni.

Other scholars have noted that around the same time, James Busby (a minor, indeed Scottish-born, British civil servant and the first official British Resident of New Zealand, appointed in 1833) was doggedly petitioning a reluctant British Crown to enter into yet another treaty with an Indigenous population (between 1760 and 1923 the British Crown generated more than 50 treaties in Canada alone). Moreover, as Smith notes, various Christian missionaries, frustrated by a marked lack of success in converting Māori, urgently wanted release from the dominating patronage of Māori chiefs and were likewise petitioning the Crown. Thus, it came to pass that the British Crown, significantly motivated by Busby's missives of an impending French gazumping, declared sovereignty over Aotearoa with the signing of the Busby-drafted Treaty of Waitangi in 1840. The Treaty foreshadowed and legally justified (at least in the eyes of the colonising British) the systematic, planned, and eventually overwhelming colonial settlement of Aotearoa by Pākehā. This started with the speculative initiatives of the New Zealand Company in 1839 , and was transcended later by similar settlement drives by provincial governments from 1853 onwards. This period witnessed the townships of Wellington, New Plymouth, Whanganui, Nelson, Dunedin, and Christchurch pop up replete with planned societies that included a minority upper class with investment capital, enough lower classes to provide labour and a market for local goods, and land prices low enough to encourage investment and commodity production, but high enough to prevent the lower classes from getting ideas above their stations.

Through detailed discussion of these five phases, Smith convincingly argues that Pākehā settlement essentially evolved from the fleeting, temporary, and archaeologically limited through to that which is increasingly prolonged, permanent, socially/economically diverse, and comparatively archaeologically enriched. Moreover, he cogently notes that resident Pākehā population increased from 12 boat builders masquerading as sealers, who in 1792 were left in Dusky Sound for nearly 12 months, to 
50 missionaries in 1814, up to 27,000 missionaries and settlers in 1851 , when the first census was taken, and then to 80,000 in 1860, when Pākehā first became numerically ascendant. As such, Smith credibly demonstrates that up until this time Mãori were effectively dominant-economically, socially, and politically_with resident (temporary and permanent) Pākehā frequently reliant on Māori for food, trading, and protection. Moreover, Māori were sometimes willingly, at other times reluctantly, 'in charge' of their Pākehā intruders.

In critically outlining these entangled archaeological assemblages of material, documentary, social, demographic, and other evidential modalities, Smith makes a particularly important contribution to the discussions and debates surrounding Pākehā colonisation of Aotearoa. Although Smith in no way situates or frames his thesis as such, I believe his book is nevertheless an important foil to those narratives that tend to Occidentalise the backgrounds, motivations, and aspirations of the various Europeans and others culpable in both historical and contemporary colonisation. Categorical notions of 'European settlers', of 'Europeans', or 'New Zealand Europeans', and indeed of 'Pākehā', are often framed as floating signifiers of colonisation and, as such, lack the specificities, nuance, and complexities that one would expect of peoples and groups drawn from a multitude of historical, social, and cultural backgrounds. Indeed, similar categorical caricature is evident whenever one glibly talks of 'Asians', 'Pasifika', and 'Māori'. Although, in lumping and defining early colonisers from Britain, Australia, North America, and elsewhere as Pākehā —and situating this term as a derivation from the East Coast term pakepakehā, which is contrasted with the Indigenous self-descriptions of 'Tongata Mauri' (tangata Māori)—Smith neatly sidesteps such Occidental caricature by foregrounding the important and consequential perspectives of Māori as a people responding to the colonial and imperial aspirations of non-Māori settlers.

Historians such as Belich and King have cogently noted the diverse cultural, ethnic, linguistic, social, and push 'n' pull backgrounds of Pākehā settlers-from the yeomen farmers of Devon, the peasants of Yugoslavia 
and Italy, and the middling failsons of Britain and their dutiful retainers (including one of my ancestors who came over as a lowly maid). Smith contributes to this nuanced understanding of colonisation by highlighting the often poorly planned, at times comical, and defectively executed early settlement by Pākehā, especially during the Sojourning Settler phase. This phase commenced in 1792 when the Britannia left a group of 12 men at Luncheon Cove, Anchor Island in the Dusky Sound to ostensibly hunt seals while the Britannia sailed on to South Africa for supplies. The group constructed two buildings, a dwelling house and a drying shed, but apparently had no direct contact with Māori. Evidence of their settlement was first discovered in 1897 by conservationist Richard Henry, although systematic archaeological excavations were not carried out until some 100 years later. Although resident until 21 October 1793, the group only procured 4,500 seals (compared to 15,000 from other stays of a similar length), and thus it appears the 'real' reason for their temporary settlement was to build a 53-foot (about 16 metres), 60-70-tonne schooner far away from the prying eyes and regulatory reach of the New South Wales authorities in Port Jackson, Sydney.

This, then, was the first Pākehā settlement of Aotearoa, although they failed to complete the schooner before the Britannia returned. Consequently, in 1795 another contract cargo ship, the Endeavour, undertook a surreptitious attempt to complete the schooner. It was joined by the Fancy, which was transporting some 50 freed convicts from Australia to Canada, but which soon after leaving Port Jackson 'discovered' another 41 stowaways (mostly escaped convicts that included former shipwrights, carpenters, and one deserter from the army). Clearly, this was a 'deliberate plot to take people capable of swiftly completing the schooner' in the Dusky Sound. ${ }^{2}$ However, the Endeavour was leaking badly when it arrived in Facile Harbour in early October 1795 and it was soon apparent that the ship was beyond repair. Some of the stranded party immediately set off to the other side of Resolution Island to finish building the schooner (the Providence), which was completed in January 1796 together with an

2 Pākehā Settlements, 74. 
extended longboat (the Assistance) in March 1796.

And thus the second 'planned', or at least intentional, and temporary Pākehā settlement effectively consisted of 244 marooned individualsincluding the first two Pākehā women and three Pākehā children. The bulk were stranded for at least three months until the Fancy and the Providence left for Norfolk Island with 64 and 90 passengers respectively, while the Assistance left for Port Jackson with 55 souls two months later. The remaining 35 were stranded for another 14 months until they were rescued by the Mercury, an American whaler. During their sojourn, this group also had no direct contact with Māori.

When this historical narrative is put beside the initial reluctance of the British Crown to declare sovereignty, or indeed to dedicate anything but minimal economic, political, and military resources to effecting engagement with, let alone control over, Aotearoa, a very different picture of early colonisation emerges from that which is popularly promulgated. Of course, from the consequential perspectives of colonised Māori-whose lands, cultures, languages, and populations have been decimated by Pākehā settlement over time-such complexity is mostly irrelevant. Moreover, it should in no way mitigate or detract attention away from the egregious colonising impacts—both historical and ongoing—on Māori. However, it should inform mature and nuanced discussions of colonisation and of the central role of globalising and imperialising capitalism-highlighting in its wake the planned, the unintended, the farcical, and the structurally predictable in circumstantial measure. Indeed it might even shift the focus of those infuriatingly glib objections to colonisation typical of talk-backradio hosts and listeners_- It wasn't me who dispossessed Māori of their lands'; 'It wasn't my ancestors who done it'-by saying: 'No, it was not you or your particular ancestral kin necessarily; however, it was the system of capitalist expansion with its attendant modalities of territorialisation, imperialism, exploitation, and stratification perpetuated under the guise of colonial authority that many of you uncritically support to this very day'. 
In sum, Pākehā Settlements in a Māori World is an excellent read and is thoroughly recommended to scholars, interested lay readers, and all those who have an opinion - of whatever hue - on the colonisation of Aotearoa New Zealand. 